\author{
Wladysław FILAR ${ }^{1}$ \\ Wieslaw KĄKOL ${ }^{2}$
}

\title{
ZNACZENIE ŚREDNICH RUCHOMYCH W PODEJMOWANIU DECYZJI INWESTYCYJNYCH NA GIELDZIE
}

\begin{abstract}
Celem opracowania jest analiza systemów transakcyjnych opartych na średnich ruchomych oraz ocena ich skuteczności w podejmowaniu decyzji inwestycyjnych na rynku papierów wartościowych. Średnie ruchome są jednymi z najstarszych i najchętniej wykorzystywanych narzędzi $\mathrm{w}$ analizie technicznej. Ich popularność wynika przede wszystkim $\mathrm{z}$ łatwości zastosowania oraz prostoty interpretacji. Dają się również wykorzystać jako elementy systemów transakcyjnych. Zastosowanie ich w praktyce inwestycyjnej nie jest jednak proste. Inwestor stoi bowiem nie tylko przed wyborem konstrukcji średniej z wielu możliwych: np. prosta, wykładnicza, ważona, itd., ale także odpowiednim dopasowaniem okresu tej średniej. Ponadto stosowanie systemu opartego na tylko jednej średniej może być problematyczne w przypadku występowania trendu horyzontalnego, wyraźne jest tez opóźnienie generowania sygnałów kupna i sprzedaży. Dlatego użytkownik najczęściej korzysta z systemu złożonego z kilku średnich. Autorzy referatu starają się w nim przybliżyć zasady działania średnich ruchomych oraz pokazać w jaki sposób mogą one zostać wykorzystane do budowania systemów transakcyjnych. Część empiryczna polega na skonstruowaniu oraz zbadaniu skuteczności kilku przykładowych systemów. Badanie polegało na analizie przydatności systemów złożonych z jednej średniej w podziale na krótko i długoterminowe. W każdym przypadku porównywano ze sobą różne rodzaje średnich. Bazę badań stanowiły wykresy cenowe spółek z indeksu WIG20 z lat 2011-2012. Wyniki zostały zaprezentowane $\mathrm{w}$ formie tabelarycznej oraz graficznej.

Słowa kluczowe: giełda, analiza techniczna, systemy transakcyjne
\end{abstract}

\section{WPROWADZENIE}

Podstawą analizy i oceny przydatności średnich ruchomych dla podejmowania decyzji inwestycyjnych stały się badania własne, których celem było zbudowanie kilku systemów transakcyjnych na bazie różnego rodzaju średnich ruchomych przetestowanych na podstawie danych giełdowych wybranych spółek wchodzących w skład indeksu WIG20 w aspekcie uzyskiwanych stóp zwrotu.

Inwestowanie na giełdzie nierozłącznie wiąże się z niepewnością i towarzyszącym jej ryzykiem. Inwestorzy starają się przewidzieć przyszłe ruchy cen instrumentów finansowych za pomocą różnego rodzaju technik, ale nigdy nie są w stanie wyeliminować z nimi związanego ryzyka. Dlatego nieustannie poszukują nowych sposobów i narzędzi, na których podstawie mogliby podejmować decyzje inwestycyjne ograniczające poziom ryzyka

\footnotetext{
${ }^{1}$ Dr hab. inż. Władysław Filar, prof. PRz, Zakład Finansów i Bankowości, Wydział Zarządzania, Politechnika Rzeszowska, al. Powstańców Warszawy 8, 35-959 Rzeszów, tel. 17 8651913, e-mail: wfilar@ prz.edu.pl.

${ }^{2}$ Dr Wiesław Kąkol (autor korespondencyjny), Zakład Finansów i Bankowości, Wydział Zarządzania, Politechnika Rzeszowska, al. Powstańców Warszawy 8, 35-959 Rzeszów, tel. 17 8651913, e-mail: kakolw@ @rz.edu.pl.
} 
ale dające też odpowiednią stopę zwrotu. Jednymi z najstarszych narzędzi wykorzystywanych do inwestowania są średnie ruchome zwane także kroczącymi. Są one wykorzystywane jako element analizy technicznej i klasyfikowane jako generatory sygnałów opóźnionych ${ }^{3}$. Obecnie w analizie technicznej wykorzystuje się różne odmiany średnich ruchomych, a także wielorakie narzędzia zbudowane na ich bazie. Niniejsze opracowanie jest analizą wykorzystywanych do podejmowania decyzji inwestycyjnych średnich ruchomych oraz próbą oceny skuteczności ich wykorzystania na podstawie przeprowadzonych badań własnych. Badania polegały na zbudowaniu kilku systemów transakcyjnych opierających się na różnego rodzaju średnich ruchomych i ich przetestowaniu pod kątem uzyskiwanych stóp zwrotu.

\section{2. ŚREDNIE RUCHOME JAKO NARZĘDZIA ANALIZY TECHNICZNEJ}

W teorii i praktyce inwestowania na giełdach wyróżnia się dwa główne podejścia: fundamentalne i techniczne. Pierwsze $\mathrm{z}$ nich najczęściej dotyczy rynku akcji i opiera się na założeniu, że cena instrumentu finansowego zależy w długim okresie od aktualnej i przyszłej sytuacji emitenta, czyli od tak zwanej wartości wewnętrznej akcji. Analiza ta powinna być stosowana przede wszystkim przez inwestorów długoterminowych i jej celem jest wskazanie, w jakie walory inwestować, natomiast czas podejmowania decyzji ma drugoplanowe znaczenie. Spółka, która dobrze prosperuje na rynku i ma perspektywy dalszego rozwoju, powinna w szybkim tempie pomnażać swoją wartość. Inwestorzy, obserwując tę progresję, będą podejmować decyzje kupna, tworząc popyt na dane akcje i tym samym sprawiać, że ich cena będzie rosła. Opierając się na analizie fundamentalnej, wystarczy więc przeanalizować spółki giełdowe i zainwestować w te, których wartość wewnętrzna akcji jest wyższa od aktualnej wartości rynkowej. Jeżeli analizy okażą się trafione, cena akcji na giełdzie powinna wzrosnąć, a inwestor będzie mógł zrealizować oczekiwane zyski. Niestety w praktyce nie jest to takie proste. Przede wszystkim wykonanie rzetelnej analizy fundamentalnej wymaga zbadania bardzo szerokiego spektrum zagadnień: począwszy od tych o charakterze makroekonomicznym, a skończywszy na bardzo subtelnych aspektach działania danego przedsiębiorstwa. Aby taką analizę przeprowadzić, trzeba mieć odpowiedni zasób danych, dużo czasu oraz wiedzy i doświadczenia w tym zakresie. Ponadto nie wszyscy inwestorzy chcą czekać na realizację swoich zysków przez dłuższy, nieraz kilkuletni okres. Wielu z nich chce uzyskiwać dochody z inwestycji w krótszych okresach. Dlatego też oprócz analizy fundamentalnej rozwinęła się analiza techniczna. Zakłada ona, że liczba czynników wpływających na cenę instrumentu finansowego na giełdzie jest nieskończona. Trudno też ustalić wagi, z jakimi czynniki te w danej chwili wpływają na cenę akcji. Dlatego też w odróżnieniu od analizy fundamentalnej $\mathrm{w}$ podejściu technicznym inwestor nie przeprowadza analiz czynników mogących mieć wpływ na cenę akcji, lecz ogranicza się do badania wcześniejszych tendencji cenowych na podstawie wykresów giełdowych. Takie postępowanie wynika z najważniejszego założenia analizy technicznej stanowiącego, że „rynek dyskontuje wszystko” - oznacza to, że wszystkie czynniki, które mogą oddziaływać na rynkową cenę papieru wartościowego - psychologiczne, polityczne, fundamentalne i inne - zawsze znajdują pełne odbicie w cenie danego instrumentu. Kształtowanie się cen odzwierciedla zmiany w relacji popytu

${ }^{3}$ J.J. Murphy, Analiza techniczna rynków finansowych, WIG PRESS, Warszawa 1999, s. 34. 
i podaży. Wykres sam w sobie nie jest więc przyczyną wzrostów czy spadków cen, lecz odzwierciedla on określoną psychologię rynku. Ponieważ założenie to nie rozwiązuje problemu przewidywania przyszłych ruchów cen, zostało uzupełnione o kolejne, wskazujące, że ceny akcji układają się $\mathrm{w}$ trendach. Jest to bardzo istotne założenie. Inwestor, który potrafi znaleźć trend, ma szanse na skorzystanie z tego ruchu i odniesienie sukcesu giełdowego ${ }^{4}$.

Kolejnym ważnym założeniem analizy technicznej jest występowanie cykliczności na rynkach, czyli powtarzania się sekwencji trendów wzrostowych i spadkowych w miarę systematyczny sposób. Analiza techniczna pozwala więc inwestorowi zorientować się, w jakim kierunku obecnie podąża rynek i podjąć odpowiednie decyzje. Nacisk w tym podejściu kładzie się bardziej na czas niż na przedmiot transakcji. Ważniejsze od tego, w jaki instrument finansowy się zainwestuje, jest określenie czasu podjęcia decyzji o zakupie oraz o sprzedaży, przy czym ta druga decyzja wbrew pozorom wydaje się ważniejsza, gdyż to od niej zależy, z jakim wynikiem ostatecznie zostanie rozliczona transakcja ${ }^{5}$.

Podejście techniczne wymaga więc przede wszystkim dokonania odpowiedniej analizy historycznych danych giełdowych prezentowanych w formie wykresów. Inwestor, który znajdzie na takim wykresie trend, może na tej podstawie rozpocząc inwestowanie, stosując podejście „gry z trendem” lub „gry przeciw trendowi”. Granie z trendem polega na podejmowaniu decyzji dopiero wtedy, gdy są już symptomy świadczące o jego ukształtowaniu ${ }^{6}$. Czyli inwestor, który chce zając pozycję długą (kupić papier wartościowy, licząc na wzrost jego ceny), powinien to zrobić dopiero wtedy, gdy widzi symptomy zakończenia się trendu spadkowego (na przykład przecięcie przez wykres cenowy linii trendu spadkowego od dołu) i rozpoczęcie wzrostowego (na przykład ukształtowanie się minimum 2 kolejnych dołków cenowych leżących jeden powyżej drugiego) ${ }^{7}$. Takie podejście daje większe prawdopodobieństwo dalszych wzrostów, gdyż rynek pokazuje istnienie trendu wzrostowego, a co za tym idzie, zmniejsza się ryzyko błędnej decyzji. Podobnie wygląda kwestia wychodzenia $\mathrm{z}$ rynku. Inwestor grający $\mathrm{z}$ trendem podejmuje decyzję sprzedaży wtedy, gdy widzi symptomy świadczące o odwróceniu trendu z wzrostowego na spadkowy (w przypadku gry na wzrosty).

Podejmowane w ten sposób decyzje mają mniejsze prawdopodobieństwo straty. Mają jednak kilka wad: przede wszystkim w praktyce wcale nie jest tak łatwo oszacować, w jakim trendzie znajduje się dany papier wartościowy. Ponadto nawet jeżeli trend został już określony, decyzje podejmowane na podstawie metody gry z trendem są opóźnione. Dlatego wielu inwestorów stara się „przechytrzyć rynek”, wyprzedzając ruchy rynku. Takie podejście nazywa się grą przeciw trendowi i polega ono na przykład na podejmowaniu decyzji kupna, gdy nadal trwa trend spadkowy, a decyzji sprzedaży, gdy inwestor osiagnął już jakiś określony zwrot z kapitału, ale rynek nadal kontynuuje trend wzrostowy. Takie podejście jest stosowane i sprawdza się, ale najczęściej w bardzo krótkoterminowym spekulowaniu na bardzo płynnych instrumentach pochodnych. W wypadku inwestycji $\mathrm{w}$ akcje nie jest raczej stosowana. Jest także sprzeczna $\mathrm{z}$ zasadą maksymalizacji

\footnotetext{
${ }^{4}$ V. Sperandeo, Trader VIC II, Wolters Kluwer Polska, Warszawa 2010, s. 156.

${ }^{5}$ M.N. Kahn, Analiza techniczna: wprowadzenie do analizy wykresów giełdowych, Wolters Kluwer, Warszawa 2011, s. 46

${ }^{6}$ V.K. Tharp, Giełda, wolność i pieniqdze. Poradnik spekulanta, WIG-PRESS, Warszawa 2000, s. 70.

${ }^{7}$ A. Zaremba, Gielda. Podstawy inwestowania, Helion, Gliwice 2010 , s. 163.
} 
zysków i minimalizacji strat, według której w przypadku kontynuacji korzystnego trendu nie powinno się zamykać pozycji, pozwalając rosnąć zyskom, natomiast w przypadku ruchów powodujących straty, powinno się jak najszybciej dane pozycje zamykać.

Tak więc jeśli inwestor będzie grać z trendem, dążąc do maksymalizacji swoich zysków, musi mieć odpowiednie narzędzia do identyfikacji tychże trendów. Najprostszym $\mathrm{z}$ nich jest naniesienie na wykres linii prostych po dołkach cenowych (w wypadku trendu wzrostowego) lub po szczytach (w wypadku spadkowego) oraz stwierdzenie, kiedy linie te przetnie wykres cenowy (rys. 1). Takie podejście nie jest jednak zbyt wygodne ani też dokładne. Może też powodować problemy interpretacyjne polegające na myleniu trendów długo- i krótkoterminowych. Przede wszystkim jednak często może dawać błędne sygnały, wtedy gdy cena na krótko przebija linię trendu lub trend gwałtownie przyspiesza lub zwalnia. W takich sytuacjach powstają krótkoterminowe zaburzenia na wykresie, które inwestor może interpretować jako zakończenie trendu. Takim sytuacjom można zapobiegać, stosując odpowiednie narzędzia analizy statystycznej, takie jak średnie ruchome. Służą one do analizy danych ułożonych w szeregach czasowych i są jednymi z częściej używanych narzędzi giełdowych. Ich zastosowanie oraz interpretacja generowanych przez nie sygnałów wcale nie są jednak proste. Zadaniem średnich giełdowych jest bowiem „wygładzenie” wykresu cenowego, dzięki czemu uzyskuje się „mniej zaszumiony” przez krótkoterminowe fluktuacje wykres cenowy i łatwiej ustalić aktualną tendencję. W praktyce linia średniej ruchomej w relacji do linii wykresu cenowego może wskazywać punkty rozpoczynania się i zakończenia trendów giełdowych ${ }^{8}$. Dzieje się tak wtedy, gdy obydwie linie się przecinają. Sygnały do zajmowania pozycji długich są generowane, gdy wykres cenowy przecina średnią od dołu, natomiast zajmuje się pozycje krótkie, gdy wykres cenowy przecina swoja średnią od góry (rys. 1).



Źródło: opracowanie własne

${ }^{8}$ E. Gately, Cena i czas. Zarys metod analizy technicznej, WIG-PRESS, Warszawa 1999, s. 37. 
Jak wynika z rysunku 1, średnie generują sygnały z opóźnieniem, a więc dopiero gdy trend na rynku się odwróci. Generalnie im dłuższy jest okres średniej ruchomej, tym opóźnienie większe, ale sygnał pewniejszy. Średnia 34-dniowa generuje sygnały kupna z dużym opóźnieniem w stosunku do średniej 9-dniowej, ale za to dużo lepiej zachowuje się w sytuacjach korekty trendu wzrostowego czy też spadkowego, pozostając poza wykresem. Średnia krótsza szybciej generuje sygnały, ale w niektórych sytuacjach, na przykład fal korekcyjnych, przecina linię wykresu cenowego, generując mnóstwo mylnych sygnałów kupna/sprzedaży. Zastosowanie dłuższej średniej opóźnia sygnał kupna/sprzedaży (sprawiając, że ewentualny zysk jest mniejszy), ale za to generuje mniej mylnych sygnałów. Bardzo ważny jest więc odpowiedni dobór okresu średniej ruchomej. Dokonuje się tego zazwyczaj w relacji do horyzontu czasowego inwestycji. Inwestorzy, którzy chcą lokować środki na kilka do kilkunastu dni, będą stosować średnie o odpowiednio krótkim terminie, natomiast inwestorzy preferujący dłuższe horyzonty czasowe mogą do wyznaczania głównych, długoterminowych trendów stosować średnie nawet kilkusetdniowe.

Ponadto średnie bardzo dobrze nadają się do generowania sygnałów kupna/sprzedaży, ale tylko wtedy gdy na rynku istnieje wyraźny trend wzrostowy lub spadkowy. W wypadku gdy rynek ,porusza się" w trendzie bocznym, średnia bardzo zbliża się do ceny bieżącej, generując dużą liczbę mylnych sygnałów. Istnieje wiele sposobów niwelowania tego problemu. Przede wszystkim można próbować doboru odpowiednich parametrów średniej, takich jak już wspomniany okres, a także rodzaj wagi, na której podstawie dane będa kształtować ostateczną wartość średniej. W praktyce stosuje się także bardziej skomplikowane rozwiązania polegające na wykorzystaniu grup średnich ruchomych lub wskaźników opracowanych na bazie kilku średnich (na przykład MACD).

\section{RODZAJE ŚREDNICH RUCHOMYCH}

Średnie ruchome mogą się między sobą różnić okresem, czyli liczbą danych, z których obliczana jest pojedyncza średnia. Teoretycznie można stosować średnie o dowolnej długości, jednak w praktyce dostosowuje się czas ich trwania do sytuacji na rynku oraz preferencji co do czasu trwania inwestycji. Przy tym należy pamiętać, że średnia giełdowa ma za zadanie wskazać punkty zwrotne trendów składających się na cykle giełdowe. Na każdy cykl składa się więc trend spadkowy i wzrostowy. Żeby dobrać średnią do długości cyklu giełdowego należy skorzystać z wzoru':

$$
\text { Dlugość_średniej_ruchomej }=\frac{\text { Dlugość _cyklu }}{2}+1
$$

Na podstawie dotychczasowych doświadczeń $\mathrm{w}$ stosowaniu średnich ruchomych stwierdzono, że niektóre z nich mają uniwersalne zastosowanie i warto stosować je jako punkt wyjścia do dalszych analiz. Najbardziej popularne okresy średnich to: 7, 9, 12, 28, 49, 100, 150, 200 dni.

Drugim parametrem średniej ruchomej jest wykorzystana waga danych branych pod uwagę $\mathrm{w}$ obliczaniu tego wskaźnika. $\mathrm{Z}$ tego punktu widzenia można wyróżnić:

- prostą średnią ruchomą,

\footnotetext{
${ }^{9}$ S.B. Achelis, Analiza techniczna od A do Z, LT\&P, Warszawa 1998, s. 212.
} 
- ważoną średnią ruchomą,

- wykładniczą średnią ruchomą,

- triangularną średnią ruchomą,

- średnią ruchomą ważoną wolumenem.

Prosta średnia ruchoma przyznaje takie same wagi każdej liczbie, z której jest obliczana. W wypadku ciągu cen akcji każda cena będzie miała taki sam wpływ na wartość średniej bez względu na to, czy była to cena sprzed n dni, czy też z wczoraj. Tę własność można traktować jako zaletę - ponieważ średnia stanowi wykładnię ceny z danego okresu i nie ma istotnych przesłanek do tego, aby różnicować wagi poszczególnych danych. $\mathrm{Z}$ kolei jednak wydaje się, że to najświeższe dane mają największy wpływ na kształtowanie ceny w kolejnych okresach. Dlatego drugim stosowanym rodzajem średniej ruchomej jest średnia wykładnicza, która nadaje wyższe wagi ostatnim danym (najświeższym). Waga zmniejsza się zgodnie z rozkładem wykładniczym funkcji dla każdej danej starszej. Taka średnia lepiej się dopasowuje i oddaje charakter ostatnich zmian, zwłaszcza gdy jest to średnia dłuższa (rys. 2).

Rys. 2. Różnice pomiędzy średnimi ruchomymi

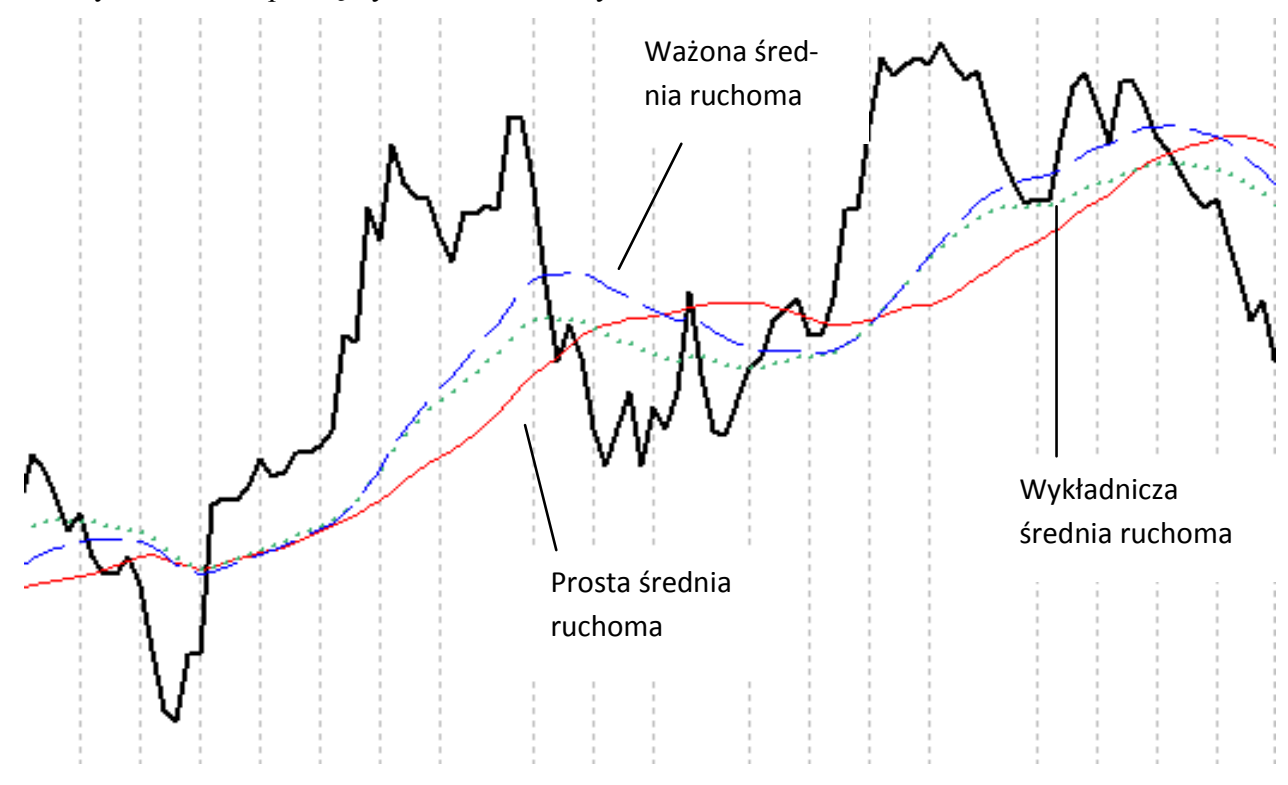

Źródło: opracowanie własne

Podobny charakter ma średnia ważona. Również nadaje wyższe wagi świeższym danym, ale rozkład tych wag jest liniowy, a nie wykładniczy. Interesującym rozwiązaniem jest stosowanie tak zwanych średnich triangularnych, czyli takich, w których najwyższe wagi nadaje się danym ze środka ich zakresu. W praktyce stosuje się też średnie ważone wolumenem, wychodząc z założenia, że większe znaczenie dla rynku mają ceny potwierdzone wysokim obrotem. Każda z tych średnich ma swoje wady i zalety. W celu porównania tych średnich i wskazania tych, które najlepiej się sprawdzają w systemach transakcyjnych, w przeprowadzonych badaniach dokonano próby porównania tych średnich oraz 
wskazania najbardziej odpowiednich pod katem wykorzystania w systemach transakcyjnych.

\section{SYSTEMY TRANSAKCYJNE BAZUJACE NA ŚREDNICH RUCHOMYCH}

Aby sprawdzić, jaki rodzaj średnich ruchomych daje najlepsze rezultaty, można przeprowadzić testy systemów transakcyjnych. Narzędzie do prowadzenia takich badań ma kilka programów komputerowych używanych do prowadzenia analizy wykresów giełdowych. W niniejszym opracowaniu testy przeprowadzono narzędziem Enhanced System Tester z programu MetaStock. Do celów badawczych zbudowano kilka systemów transakcyjnych:

1. Systemy krótkoterminowe:

- $\quad$ system transakcyjny oparty na prostej średniej ruchomej - 12-dniowej

- $\quad$ system oparty na wykładniczej średniej ruchomej - 12-dniowej

- $\quad$ system oparty na średniej ważonej - 12-dniowej

2. Taki sam zestaw testów wykonano dla średniej długoterminowej - 100-dniowej.

Założono, że wszystkie średnie w danej grupie będą miały taki sam okres, po to by móc porównać wyniki między sobą. Badania przeprowadzono na podstawie danych dotyczących cen akcji pięciu spółek z indeksu WIG20: KGHM, PGE, PKO BP, Lotos, TVN z okresu od 1 stycznia 2011 do 31 grudnia 2012 r. Spółki wybrano w ten sposób, żeby prezentowały na przestrzeni założonego okresu czasu różne wyniki, a więc także różne warunki dla poszczególnych systemów. Pozwoli to na uogólnienie przedstawionych wniosków. System testujący zestrojono tak, aby mierzyć rentowność tylko pozycji długich (bez krótkiej sprzedaży), z założeniem występowania prowizji od przeprowadzanych transakcji w wysokości $0,4 \%$ za każdą transakcję kupna/sprzedaży. W pierwszych dwóch grupach testów przyjęto, że sygnał kupna będzie generowany, gdy wykres cenowy przetnie wykres średniej od dołu, czyli przy spełnieniu warunku: $\operatorname{Cross}(C, \operatorname{Mov}(C, 12, S))$, natomiast sygnał sprzedaży, gdy wykres cenowy przetnie średnią od góry, czyli $\operatorname{Cross}(\operatorname{Mov}(C, 12, S), C)$. Założono również, że wszystkie transakcje będą realizowane $\mathrm{w}$ chwili wygenerowania sygnału kupna/sprzedaży.

Wyniki przeprowadzonych testów za pomocą średniej krótkoterminowej przedstawiono w tabeli 1.

Tabela 1. Wyniki testowania systemów opartych na różnych odmianach średniej ruchomej 12-dniowej w \% stopy zwrotu

\begin{tabular}{|l|l|l|l|l|l|}
\hline \multicolumn{1}{|c|}{ System } & Bogdanka & KGHM & PGE & PKOBP & TVN \\
\hline $\begin{array}{l}\text { Prosta średnia } \\
\text { ruchoma 12- } \\
\text { dniowa }\end{array}$ & 98,4 & 193,4 & 22,9 & 10,9 & 13,0 \\
\hline $\begin{array}{l}\text { Wykładnicza } \\
\text { średnia ruchoma }\end{array}$ & 113,9 & $24 / 6$ & $29 / 22$ & $31 / 16$ & $26 / 8$ \\
12-dniowa & $33 / 16$ & $26 / 7$ & $34 / 19$ & $34 / 17$ & $32 / 5$ \\
\hline $\begin{array}{l}\text { Ważona średnia } \\
\text { ruchoma 12- } \\
\text { dniowa }\end{array}$ & 118,3 & 229,4 & 27,6 & 14,5 & 16,2 \\
\hline
\end{tabular}

Źródło: opracowanie własne 
Przedstawione dane prezentują procentową stopę zwrotu z zainwestowanego kapitału oraz poniżej każdej z danych liczbę transakcji zyskownych/liczbę transakcji stratnych. Najlepiej w zestawieniu wypadło wykorzystanie średniej ruchomej ważonej, w której wagi są przypisywane liniowo do poszczególnych danych w kolejności od najmniejszej (przy najstarszej cenie w okresie) do największej (przy najmłodszej cenie w okresie). Najlepszy rezultat osiagnęliby inwestorzy na akcjach KGHM - 229,4\% stopy zwrotu, dokonując 30 transakcji zyskownych oraz 13 stratnych. Ponieważ system nie zakładał żadnego dodatkowego zabezpieczenia w postaci linii stopu, największa strata w pojedynczej transakcji wyniosła 5,8\%, ale najwyższy zysk w pojedynczej transakcji wyniósł 26,1\%. Bardzo dobry wynik KGHM jest związany z korzystnymi wahaniami kursu akcji w analizowanym okresie, a zwłaszcza w jego końcowej części. Cena akcji KGHM od początku 2011 do końca 2012 r. wzrosła o 11,7\%, stosowanie każdego z testowanych systemów dawało lepsze rezultaty. Najniższe wyniki osiągały w porównaniu z innymi systemy testowane na spółce PKO BP. Cena akcji tej spółki w analizowanym okresie spadła o 15\%, ponadto w roku 2011 występował silny trend spadkowy, a rok 2012 przebiegał w trendzie bocznym, a więc bardzo „niewygodnym” dla wskaźników, takich jak średnie ruchome (rys. 3).

Rys. 3. Wykres cenowy akcji PKO BP wraz z średnią ruchomą 12-dniową oraz 100-dniową ważoną w latach 2011-2012



Źródło: opracowanie własne

Pomimo tego można postawić wniosek że krótkoterminowe średnie dały lepsze wyniki niż strategia trzymania akcji przez cały okres. Ponadto najlepszy rezultat osiagnięto stosując średnią ważoną.

W celu sprawdzenia jak zachowują się średnie długoterminowe przeprowadzono testy 100 dniowej średniej ruchomej w różnych odmianach. Wyniki badań przedstawiono w tabeli 2. 
Tabela 2. Wyniki testowania systemów opartych na różnych odmianach średniej ruchomej 100-dniowej

\begin{tabular}{|l|l|l|l|l|l|}
\hline \multicolumn{1}{|c|}{ System } & Bogdanka & KGHM & PGE & PKOBP & TVN \\
\hline $\begin{array}{l}\text { Prosta średnia } \\
\text { ruchoma 100- }\end{array}$ & 32,4 & 40,1 & 4,1 & 0,2 & 1,71 \\
dniowa & $11 / 11$ & $6 / 4$ & $10 / 6$ & $8 / 7$ & $4 / 4$ \\
\hline $\begin{array}{l}\text { Wykładnicza } \\
\text { średnia ruchoma }\end{array}$ & 40,4 & 60,0 & 3,0 & 0,8 & 2,8 \\
100-dniowa & $15 / 16$ & $9 / 3$ & $8 / 6$ & $11 / 8$ & $6 / 2$ \\
\hline $\begin{array}{l}\text { Ważona średnia } \\
\text { ruchoma 100- }\end{array}$ & 32,2 & 77,9 & 7,0 & 3,6 & 4,6 \\
dniowa & $10 / 13$ & $9 / 4$ & $9 / 7$ & $11 / 3$ & $9 / 2$ \\
\hline
\end{tabular}

Źródło: opracowanie własne

Również w tym zestawieniu najlepszy okazał się system oparty na średniej ruchomej ważonej, chociaż w wypadku akcji Bogdanki SA, lepsza okazała się średnia wykładnicza. Warto jednak zauważyć, że zastosowanie średniej wykładniczej niosło ze sobą duże ryzyko. Aż 16 z 31 transakcji kończyło się stratą. Wynika to bezpośrednio z przebiegu wykresu (rys. 4).

Rys. 4. Wykres kursu akcji Bogdanki SA oraz średniej ruchomej 100-dniowej ważonej w latach 2011-2012



Źródło: opracowanie własne

Rok 2011 był czasem korekty po trendzie wzrostowym trwającym od roku 2009 (debiut na giełdzie). Na początku roku 2012 nastąpiło odreagowanie, lecz następnie cena pozostawała w wąskim trendzie bocznym i dopiero z końcem roku wybiła się w górę. Nie był to dobry okres dla średniej 100-niowej. Prawdopodobnie lepiej zachowywałaby się średnia 200-dniowa, ponieważ nie generowałaby tylu mylnych sygnałów w fazie trendu bocznego. 
Rys. 5. Wykres akcji spółki KGHM i jego średniej ruchomej ważonej 100-dniowej oraz u góry wykres zysków

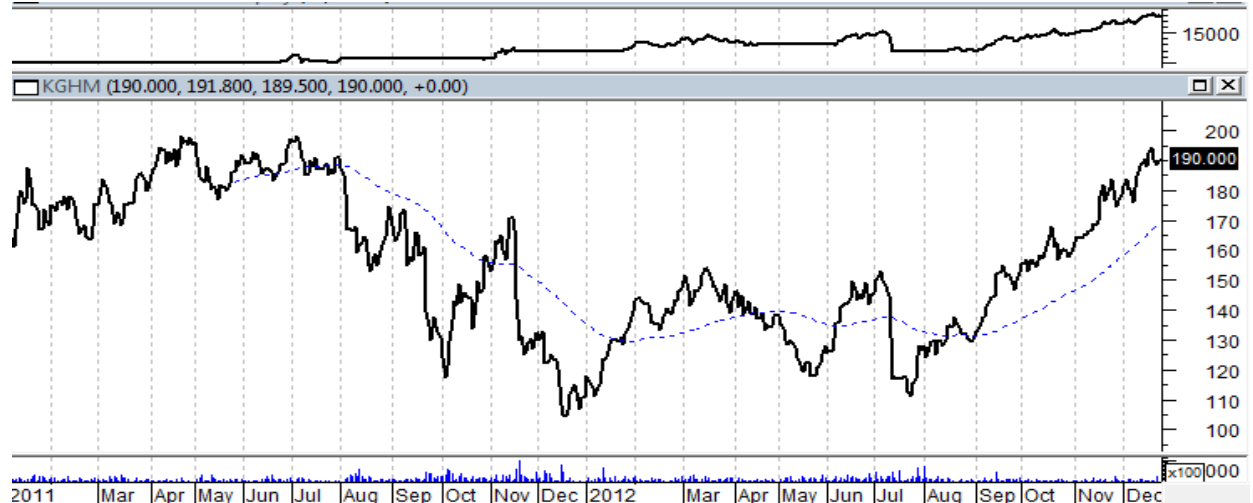

Źródło: opracowanie własne

Najlepsze wyniki zostały osiagnięte podobnie jak w wypadku średnich krótkoterminowych na akcjach KGHM (rys. 5) za pomocą średniej ważonej. Podążała ona szybciej za trendem niż prosta średnia ruchoma, niwelując w pewnym stopniu problem dużego opóźnienia.

W przeprowadzonych testach średnie długoterminowe zasadniczo wypadły gorzej niż krótkoterminowe, co nie oznacza, że tak jest zawsze. Średnie długoterminowe mogą bowiem być podstawą bardziej efektywnych systemów niż krótkoterminowe przy bardzo długim horyzoncie czasowym obejmującym najbardziej znaczące cykle giełdowe, czyli w wypadku giełdy w Warszawie cykl 3-4-letni. Ponadto przy długich średnich warto dodatkowo stosować wybraną strategię ochrony kapitału w postaci odpowiednich linii stopu. Zbyt duże opóźnienie średnich o długich okresach może powodować dotkliwe spadki wartości portfela.

\section{PODSUMOWANIE}

Pomimo że średnie ruchome to jedne z najstarszych narzędzi stosowanych do analizowania wykresów cenowych, nic nie straciły na swojej aktualności. Metoda uśredniania bardzo dobrze sprawdza się w badaniu przebiegu trendów oraz budowaniu systemów transakcyjnych. W przeprowadzonych doświadczeniach wykazano, że bazując na średnich ruchomych, można zbudować bardziej efektywne strategie inwestycyjne. Wykazano również, że dobrze jest stosować średnie, które faworyzują nowsze dane, czyli średnie ważone lub też ekspotencjalne. Bardzo istotny jest również odpowiedni dobór okresu średniej. Należy tego dokonywać w bezpośredniej relacji do horyzontu czasowego danej inwestycji. Warto także mieć na uwadze, że średnie o krótszych okresach będą generować o wiele więcej sygnałów kupna/sprzedaży, angażując tym samym czas inwestora oraz narażając go na zwiększone koszty transakcyjne. Natomiast z jednej strony średnie o dłuższych okresach dają pewniejsze sygnały, ale z drugiej strony są bardziej opóźnione, nadają się więc do inwestowania $\mathrm{z}$ wykorzystaniem długich trendów. Z kolei trend horyzontalny (nawet o kilkunastoprocentowej amplitudzie wahań) nie będzie sprzyjał systemom opartym na średnich z długimi okresami. 


\section{LITERATURA}

[1] Achelis S.B., Analiza techniczna od A do Z, LT\&P, Warszawa 1998.

[2] Gately E., Cena i czas. Zarys metod analizy technicznej, WIG-PRESS, Warszawa 1999.

[3] Kahn M.N., Analiza techniczna: wprowadzenie do analizy wykresów giełdowych, Wolters Kluwer, Warszawa 2011.

[4] Murphy J.J., Analiza techniczna rynków finansowych, WIG PRESS, Warszawa 1999.

[5] Sperandeo V., Trader VIC II, Wolters Kluwer Polska, Warszawa 2010.

[6] Tharp V.K., Giełda, wolność i pieniqdze. Poradnik spekulanta, WIG-PRESS, Warszawa 2000.

[7] Zaremba A., Gietda. Podstawy inwestowania, Helion, Gliwice 2010.

\section{MEANING OF MOVING AVERAGE IN INVESTMENT DECISION MAKING}

Investing in the stock market is to take risky decisions. The behavior of financial markets depends on so many variables whose the analysis and prediction is a very difficult task. Therefore, investors are always looking for methods and techniques which give a higher probability of success. The aim of this paper is to analyze transactional systems based on moving averages and assess their effectiveness in making investment decisions on the securities market. Moving averages are one of the oldest tools used to analyze and predict price movements. They have many advantages, but it does not mean that their use is easy. The investor needs to know exactly what the characteristics of each type of averages are, how to select the parameters for their own style of investing. Only then one can create a successful trading system that will generate some signs of purchase and sales. This article is an attempt to systematize the knowledge and experience of the authors in this field.

Keywords: stock exchange, technical analysis, transactional systems

DOI: $10.7862 /$ rz.2013.mmr.3

Teks złożono w redakcji: styczeń 2013

Przyjęto do druku: czerwiec 2013 